\title{
BIOGRAPHICAL SKETCH OF THE AUTHOR
}

Noah Smithwick was born in Martin Co., N. C., on the Ist day of January I8o8. He came of good old revolutionary stock, his ancestors on both sides having fought in the patriot army. The Smithwicks came from England to America early in the I8th century, procuring land in North Carolina, the original title deeds to which, bearing date of $\mathrm{I} 66 \mathrm{I}$, are still in the family. The family was of Scotch descent. Edward, the father of Noah Smithwick, moved to Tennessee in 1814 , settling near Springfield, from which place the son drifted with the tide of emigration to Texas in 1827 ; remaining with the state till I86I, when he moved on to California, settling first in Tulare Co., and later at Santa Anna, Orange Co., at which latter place he died Oct. 2 I, I899, aged $9 \mathrm{I}$ years, 9 months and $2 \mathrm{I}$ days. His wife, Thurza N. (Blakey) Smithwick (prior to her marriage to him the widow Duty), also a pioneer Texan, died in I87 I. Of their five children but two survive; Edward, in Santa Anna, Cal., and the writer of this sketch, now in Texas.

Nanna Smithwick Donaldson 
THIS PAGE INTENTIONALLY LEFT BLANK 


\section{The Evolution of a State}


THIS PAGE INTENTIONALLY LEFT BLANK 